\title{
ANALISIS TINGKAT KESEHATAN BANK DENGAN METODE RGEC PADA PT BANK MEGA TBK TAHUN 2015-2018
}

\author{
Muhammad Syafnur \\ Sekolah Tinggi Ilmu Ekonomi (STIE) Pembangunan Tanjungpinang \\ m.syafnur@stie-pembangunan.ac.id \\ Rachmad Chartady \\ Sekolah Tinggi Ilmu Ekonomi (STIE) Pembangunan Tanjungpinang \\ chartady@stie-pembangunan.ac.id
}

\begin{abstract}
Abstrak: Penelitian ini memiliki tujuan untuk mengetahui dan menganalisis tingkat kesehatan pada PT. Bank Mega, Tbk. Data yang digunakan dalam penelitian ini adalah berupa data laporan keuangan PT. Bank Mega, Tbk tahun 2016-2018. Adapun jenis penelitian ini merupakan jenis penelitian kuantitatif dan metode yang digunakan untuk menganalisis tingkat kesehatan bank adalah dengan menggunakan metode RGEC (Risk Profile, Good Governance (GCG), Earnings dan Capital). Hasil peneltian menunjukkan bahwa PT. Bank Mega, Tbk selama periode 2016-2018 mendapatkan tingkat komposit 1 dengan predikat sangat sehat dan dilihat dari Rasio NPL (Non Performing Loan) dan Rasio LDR (Loan to Deposit Ratio) menunjukkan bahwa PT Bank Mega Tbk mampu mengelola risiko kreditnya dengan baik. Tata kelola Bank telah dilakukan dengan baik menurut penilaian GCG (Good Corporate Governance) sehingga memperoleh peringkat sehat. Berdasarkan pada analisis perhitungan ROA (Return on Assets) dan NIM (Net Interest Margin) menunjukkan bahwa kemampuan bank dalam memperoleh laba tinggi walaupun ada penurunan pada NIM (Net Interest Margin) namun bank tetap dikatakan dalam predikat yang sangat sehat. Bank Mega mampu mengelola permodalannya, hal tersebut dapat dilihat dari rasio CAR yang lebihbesar dari $12 \%$ sesuai dengan peraturan Bank Indonesia, sehingga rasio permodalan pada PT Bank Mega dikatakan sangat sehat.
\end{abstract}

Kata Kunci: Tingkat kesehatan bank, RGEC (Risk Profile, Good Corporate Governance, Earnings dan Capital)

Abstract: This study aims to determine and analyze the level of health at PT. Bank Mega, Tbk. The
data used in this research is in the form of financial statement data for PT. Bank Mega, Tbk in
2016-2018. This type of research is a type of quantitative research and the method used to analyze
the level of health is by using the RGEC method (Risk Profile, Good Governance (GCG), Earnings
and Capital). The research results show that PT. Bank Mega, Tbk during the 2016-2018 period
received a composite level 1 with a very healthy predicate and seen from the NPL (Non-Performing
Loan) Ratio and the LDR (Loan to Deposit Ratio) ratio, it shows that PT Bank Mega Tbk is able to
manage its credit risk well. The Bank's governance has been carried out well according to the GCG
(Good Corporate Governance) assessment so that it has obtained a healthy rating. Based on the
analysis of ROA (Return on Assets) and NIM (Net Interest Margin) calculations, it shows that the
bank's ability to earn high profits even though there is a decrease in NIM (Net Interest Margin), the
bank is still said to be in a very healthy predicate. Bank Mega is able to manage its capital, this can
be seen from a CAR ratio that is greater than $12 \%$ in accordance with Bank Indonesia regulations,
so that the capital ratio at PT Bank Mega is said to be very healthy.

Keywords: Bank Soundness Level, RGEC (Risk Profile, Good Corporate Governance, Earnings and Capital. 


\section{PENDAHULUAN}

Sektor perbankan merupakan sektor yang mempunyai peranan yang sangat penting dalam meningkatkan ekonomi suatu negara. Perbankan merupakan salah satu roda perekonomian di Indonesia karena perbankan memiliki peranan dalam menghimpun, menyalurkan dan memberikan pelayanan jasa dalam pembayaran dan peredaran uang di masyarakat. Bank adalah lembaga yang menyediakan berbagai produk, baik itu produk dasar maupun produk utama dalam bentuk pinjaman maupun impanan sehingga bank memiliki peran sebagai intermediaris antara pemilik dana (Surplus Spending Unit) dan peminjaman dana (Defisit Spending Unit).

Bank adalah lembaga keuangan yang menjadi tempat bagi perorangan, badan atau perusahaan untuk menyimpan atau menitipkan dananya. Selain itu, bank juga memberikan pelayanan kepada masyarakat baik memberikan pelayanan dalam pembiayaan dan memberikan kelancaran pada mekanisme sistem pembayaran atas transaksi yang terjadi pada semua sektor perekonomian.

Sebagai lembaga intermediasi, bank harus dapat memperhatikan tingkat kesehatannya karena tingkat kesehatan bank sangat berguna bagi pihak baik pihak internal maupun eksternal untuk mengetahui pergerakan dan perkembangan dari kinerja perbankan tersebut dalam menerapkan prinsip kepatuhan, kehati- hatian dan manajemen risiko. Penilaian tingkat kesehatan bank sangat penting mengingat bahwa masyarakat percaya untuk menitipkan dananya pada bank.

Kesehatan bank adalah kemampuan bank dalam menjalankan berbagai kegiatankegiatan operasional perbankan secara normal maupun dalam upaya memenuhi kewajiban berdasarkan pada peraturan yang berlaku. Kesehatan bank sangatlah penting bagi berbagai pihak terkait baik pengelola, pemilik, masyarakat maupun Bank Indonesia sebagai bank yang membina dan mengawasi kegiatan perbankan di Indonesia.

Tingkat kesehatan bank yang baik akan memberikan berbagai manfaat yang besar bagi bank untuk mendapatkan kepercayaan dari masyarakat. Tingkat kesehatan bank juga merupakan sarana untuk mengevaluasi kinerja dari berbagai permasalahan yang dihadapi oleh perbankan serta menindaklanjuti berbagai permasalahan dan kelemahan dari bank.

Berdasarkan pada Peraturan Bank Indonesia (PBI) Nomor 13/1/PBI/2011 tanggal 5 Januari 2011 menyatakan bahwa tingkat kesehatan bank dapat diartikan sebagai hasil dari penilaian secara kualitatif atas berbagai aspek yang dapat mempengaruhi kondisi atau kinerja dari suatu bank melalui berbagai penilaian secara kuantitatif maupun kualitatif terhadap berbagai faktor seperti profil risiko, Good Corporate Governance (GCG), rentabilitas, dan permodalan. Bank Indonesia merupakan 
Bank Sentral Indonesia yang menetapkan berbagai kebijakan berkaitan dengan tingkat kesehatan bank umumdengan metode CAMELS yang tercantum dalam Peraturan Bank Indonesia (PBI) No. 6/10/PBI/2004 tanggal 12 April 2004. Metode CAMELS kemudian disempurnakan oleh Bank Indonesia menjadi metode RGEC (Risk Profile, Good Corporate Governance, Earning, dan Capital) yang kemudian tertuang dalam Surat Edaran Bank Indonesia Nomor 13/24/DPNP tanggal 25 Oktober 2011 tentang Penilaian Tingkat Kesehatan Bank Umum.

Berbagai hal terkait dengan penilaian telah ditetapkan dalam lima Peringkat Komposit (PK) berdasarkan pada PBI Nomor 13/1/PBI/2011 yang memuat tentang penialian tingkat kesehatan Bank Umum dan peringkat penilaian komposit bank yang ditetapkan berdasarkan analisis yang terstruktur dan komprehensif terhadap peringkat dengan tetap memperhatikan signifikansi maupun materialitas dari setiap faktor.

Salah satu perbankan di Indonesia adalah PT. Bank Mega Indonesia yang merupakan perusahaan Indonesia yang berbentuk Perseroan Terbatas yang bergerak di bidang keuangan perbankan yang visinya antara lain menjadi bank kebangsaan bangsa dan untuk mencapai tujuan tersebut PT. Bank Mega harus mampu memberikan pelayanan yang baik, menjadi acuan tata kelola yangb baik bagi perusahaan. PT. Bank Mega, Tbk memiliki nilai aset yang fluktuatif dari tahun ke tahun yaitu dari tahun 2015-2018. Hal ini dapat dilihat pada grafik berikut :

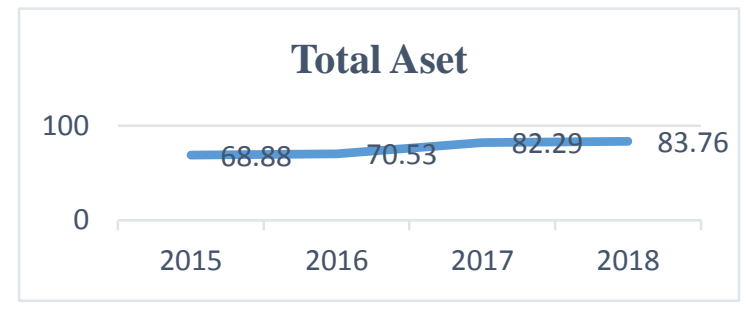

Sumber: Laporan Keuangan PT. Bank Mega, Tbk Tahun 2015-2018

Grafik 1

Total Aset PT. Bank Mega, Tbk.

Grafik 1 menunjukkan bahwa total aset PT. Bank Mega, Tbk mengalami peningkatan dari tahun 2015-2018. Hal tersebut menunjukkan bahwa PT. Bank Mega, Tbk memiliki aset yang terus meningkat setiap tahunnya. Selain total aset, laba bersih yang dihasilkan oleh PT. Bank Mega Tbk meningkat dari tahun 2015-2018 sebagaimana disjikan dalam grafik sbeagai berikut:

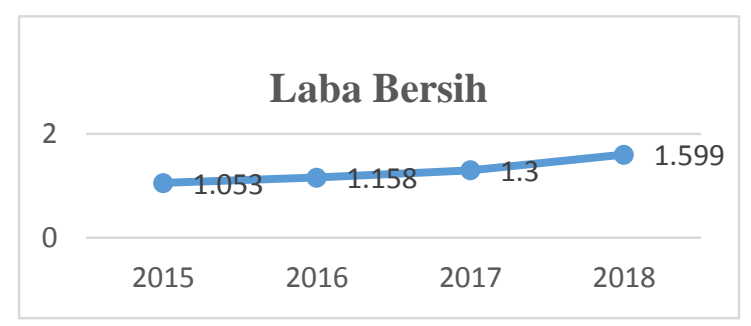

Sumber: Laporan Keuangan PT. Bank Mega, Tbk, 2020.

Grafik 2

Laba Bersih PT. Bank Mega, Tbk.

Grafik 2 diatas menunjukkan bahwa dari tahun 2015 sampai dengan tahun 2018 PT. Bank Mega, Tbk mengalami peningkatan laba bersih setiap tahunnya. Peningkatan laba bersih yang terjadi pada PT. Bank Mega, Tbk ini terjadi karena semakin meningkatnya 
pendapatan yang diterima oleh bank setiap tahunnya namun pada tahun 2016 terjadi permasalahan dalam perkreditan yang ditunjukkan dengan rasio NPL (Non performing Loan). Rasio Non Performing Loan (NPL) PT. Bank Mega, Tbk disajikan pada grafik berikut:

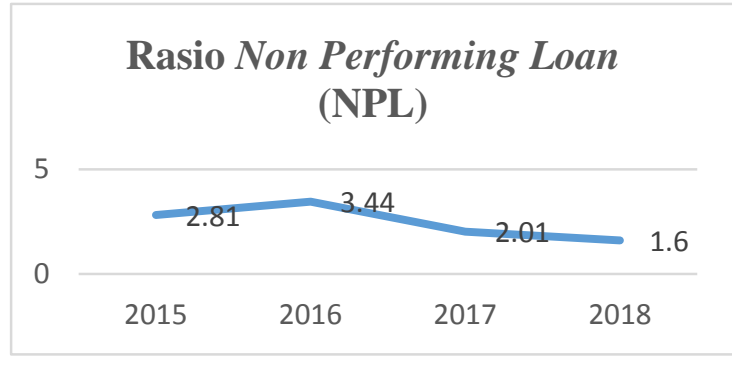

Sumber: Laporan Keuangan PT. Bank Mega, Tbk Tahun 2015-2018

\section{Grafik 3}

Rasio NPL PT. Bank Mega, Tbk.

Grafik 3 diatas menunjukkan bahwa rasio Non Performing Loan PT. Bank Mega, Tbk mengalami fluktuasi dari tahun 2015 ke tahun 2016 meningkat sebesar 0,63 persen dan dari tahun 2016 ke tahun 2017 dan pada tahun 2018 rasio NPL mengalami penurunan. Dengan semakin meningkatnya rasio NPL akan berdampak buruk pada bank tersebut. Tingginya rasio NPL menandakan bahwa kinerja bank dalam mengelola kredit bermasalah kurang baik.

Berdasarkan pada latar belakang diatas maka peneliti tertarik untuk menganalis kesehatan bank pada PT. Bank Mega, Tbk dengan menggunakan metode RGEC (Risk Profile, Good Corporate Governance, Earnings, Capital).

\section{METODOLOGI PENELITIAN}

\section{Rancangan Penelitian}

Penelitian ini menggunakan pendekatan penelitian kuantitatif. Pendekatan kuantitatif bertujuan untuk menguji teori, membangun fakta, menunjukkan hubungan antar variabel, memberikan deskripsi statistik, menaksir dan meramalkan hasilnya. Sedangkan desain penelitian dalam penelitian ini adalah penelitian deskriptif yaitu menganalisis tingkat kesehatan PT. Bank Mega, Tbk dengan cara menganalisis data laporan keuangan dan kemudian ditabulasi untuk menentukan kategori tingkat kesehatan bank.

\section{Populasi dan Sampel Penelitian}

Populasi dalam penelitian ini adalah laporan keuangan tahunan PT. Bank Mega, Tbk, sedangkan sampel dalam penelitian ini adalah laporan keuangan PT. Bank Mega Tbk tahun 2015-2018. Teknik pengambilan sampel dilakukan dengan teknik Purposive Sampling yaitu teknik pengambilan sampel dengan kriteria tertentu.

\section{Teknik Pengumpulan Data dan Pengembangan Instrumen}

Jenis data dalam penelitian ini adalah data sekunder yaitu data berupa laporan keuangan PT. Bank Mega, Tbk tahun 2015-2018 yang diperoleh melalui website www.idx.com. Adapun metode pengumpulan data dalam penelitian ini dilakukan dengan studi pustaka yaitu teknik pengumpulan data yang bersumber dari berbagai literatur dan laporan laporan pendukung yang diperoleh dari situs resmi PT. Bank Mega, Tbk. 


\section{Teknik Analisis Data}

Teknik analisis data dalam penelitian ini adalah teknik analisis data kuantitatif dengan rasio keuangan dan peringkat komposit dari setiap aspek tingkat kesehatan bank dalam metode RGEC yaitu Risk Profile, Good Corporate Governance, Earning dan Capital.

\section{Risk Profile (Profil Risiko)}

Berdasarkan pada Peraturan Otoritas Jasa Keuangan Nomor 4/POJK.03/ 2016 tentang penilaian tingkat kesehatan bank menggunakan pendekatan berbasis risiko.

1. Risiko Kredit

Risiko kredit adalah risiko akibat dari kegagalan debitur dan atau pihak kreditur dalam memenuhi kewajiban terhadap bank. Risiko kredit dihitung menggunakan rasio NPL (Non Performing Loan). Berdasarkan lampiran surat edaran bank Indonesia No.13/24/DPNP/ 2011 perhitungan NPL, sebagai berikut :

$$
N P L=\frac{\text { Kredit Bermasalah }}{\text { Total Kredit }} \times 100 \%
$$

2. Risiko likuiditas

Risiko likuiditas merupakan risiko untuk melihat kemampuan bank dalam memenuhi kewajiban baik jangka pendek maupun yang sudah jatuh tempo. Risiko ini juga disebut sebagai risiko likuiditas pendanaan (funding liquidity risk). Risiko likuiditas diukur dengan menggunakan rasio Loan to Deposit Ratio (LDR). Berdasarkan lampiran surat edaran bank Indonesia No.13/24/DPNP/2011 perhitungan LDR, sebagai berikut :

$$
L D R=\frac{\text { Total Kredit }}{\text { Dana Pihak Ketiga }} \times 100 \%
$$

\section{Good Corporate Governance (GCG)}

GCG adalah penilaian terhadap penilaian kualitas manajemen bank. Prinsip GCG dan fokus penilaian terhadap prinsip GCG berstandar pada ketentuan Bank Indonesia mengenai pelaksanaan GCG bagi bank umum dengan memperhatikan karakteristik dan kompleksitas bank.

\section{Earnings}

Penilaian kesehatan bank dari sisi rentabilitas. Penilaian faktor rentabilitas meliputi evaluasi terhadap kinerja rentabilitas, Penilaian dilakukan dengan cara mempertimbangkan tingkat trend, struktur, stabilitas retabilitas Bank, dan perbandingan kinerja Bank dengan kinerja peer group, baik melalui analisis aspek kuantitatif maupun kualitatif. Indikator penilaian rentabilitas ada 2 yaitu ROA dan NIM.

1. ROA (Return On Assets), rasio ini digunakan dalam mengukur efisiensi dari penggunaan asset dalam menghasilkan laba. Perhitungan ROA sebagai berikut:

$$
R O A=\frac{\text { Laba Sebelum Pajak }}{\text { Rata }- \text { Rata Total Aset }} \times 100 \%
$$

2. NIM (Net Interest Margin), rasio ini digunakan dalam mengukur pengelolaan aktiva produktif sehingga 
menghasilkan pendapatan bunga bersih.

Perhitungan NIM sebagai berikut:

$$
N I M=\frac{\text { Pendapatan Bunga Bersih }}{\text { Rata }- \text { Rata Aktiva Produktif }} \times 100 \%
$$

\section{Capital}

CAR (Capital Adequacy Ratio), rasio ini digunakan dalam mengukur kecukupan modal untuk menunjang aktiva yang mengandung atau menghasilkan aktiva. Perhitungan CAR sebagai berikut:

$$
\text { CAR }=\frac{\text { Modal }}{\text { ATM }} \times 100 \%
$$

\section{HASIL DAN PEMBAHASAN}

Berdasarkan Surat Edaran Bank Indonesia No. 13/1/PBI/2011 dan SE No. 13/24/DPNP tanggal 25 Oktober 2011 tentang Sistem Penilaian Tingkat Kesehatan Bank Umum, Penilaian kesehatan bank umum PT. Bank Mega, Tbk. Tahun 2015-2018 meliputi faktor-faktor sebagai berikut :

\section{Profil Risiko (Risk Profile)}

\section{Non Performing Loan (NPL)}

Tabel 1

Nilai NPL PT. Bank Mega, Tbk.

\begin{tabular}{|c|c|}
\hline Tahun & NPL (\%) \\
\hline 2015 & 2,81 \\
\hline 2016 & 3,44 \\
\hline 2017 & 2,01 \\
\hline 2018 & 1,60 \\
\hline
\end{tabular}

Sumber: Hasil Olahan, 2019

Berdasarkan Tabel 1 diatas, dapat diketahui perolehan nilai rasio NPL pada PT. Bank Mega, Tbk. dari tahun 2015 - 2018 terjadi fluktuasi. Dapat dilihat ditahun 2016 mengalami kenaikan nilai rasio NPL, dari yang sebelumnya memperoleh sebesar 2,81\% ditahun 2015 menjadi 3,44\% ditahun 2016. Ditahun 2017 - 2018 nilai rasio NPL mengalami penurunan, PT. Bank Mega, Tbk. memperoleh nilai rasio NPL yaitu sebesar 2,01\% ditahun 2017 dan mengalami penurunan lagi ditahun 2018, dengan nilai rasio NPL yang diperoleh yaitu sebesar $1,60 \%$. Hal ini menunjukan bahwa nilai rasio NPL PT. Bank Mega dari tahun 2015 - 2018 cenderung menurun.

Dengan nilai rasio yang semakin menurun maka kinerja pada suatu bank akan semakin baik, berlaku sebaliknya jika semakin besar nilai rasio NPL yang diperoleh maka akan semakin menurun kinerja pada suatu bank. Jika suatu bank memiliki kecenderungan menurun pada nilai rasio NPL menandakan bahwa bank tersebut sudah mampu mengatasi permasalahan kredit yang terjadi. Jika bank sudah mampu mengatasi kredit bermasalah dengan baik walaupun terjadi kredit yang dikategorikan tidak lancar, kredit yang diberikan akan tetap meningkat, sehingga bank tersebut akan tetap stabil.

\section{Loan to Deposit Ratio (LDR)}

Tabel 2

Nilai LDR PT. Bank Mega, Tbk.

\begin{tabular}{|c|c|}
\hline Tahun & LDR (\%) \\
\hline 2015 & 65,05 \\
\hline 2016 & 55,35 \\
\hline 2017 & 56,47 \\
\hline 2018 & 67,23 \\
\hline
\end{tabular}

Sumber: Hasil Olahan, 2019

Berdasarkan tabel 2 diatas, dapat diketahui nilai rasio LDR yang diperoleh oleh PT. Bank Mega, Tbk. dari tahun 2015 - 
2018 terjadi kenaikan maupun penurunan.

Ditahun 2015 diperoleh nilai rasio LDR sebesar $65,05 \%$ dan mengalami penurunan ditahun 2016 menjadi 55,35\%.

Kemudian ditahun 2017-2018 mengalami kenaikan nilai rasio LDR secara berturutturut yaitu sebesar 56,47\% ditahun 2017 dan 67,23\% ditahun 2018. Terlihat dari tahun 2015 - 2018, nilai rasio LDR yang diperoleh PT. Bank Mega, Tbk. memiliki kecenderungan semakin meningkat. Hal ini menunjukan bahwa semakin meningkatnya nilai rasio LDR yang diperoleh maka akan semakin menurun kinerja pada bank tersebut dalam mengelola perkreditan, karena jumlah dana yang dikeluarkan untuk keperluan kredit terlalu besar sehingga menyebabkan likuiditas semakin menurun.

\section{Risiko Pasar}

Tabel 3

Nilai Peringkat Risiko Pasar PT. Bank

\begin{tabular}{|c|c|}
\multicolumn{1}{c}{ Mega, Tbk } \\
\hline Tahun & Peringkat \\
\hline 2015 & 2 \\
\hline 2016 & 2 \\
\hline 2017 & 2 \\
\hline 2018 & 2 \\
\hline
\end{tabular}

\section{Sumber: Hasil Olahan, 2019.}

Berdasarkan tabel 3, dapat dilihat bahwa peringkat risiko pasar yang diperoleh pada PT. Bank Mega, Tbk. dari tahun 2015 - 2018 sangat stabil karena secara berturut-turut memperoleh peringkat 2. Hal ini menunjukan bahwa dengan mempertimbangkan aktivitas bisnis yang dilakukan PT. Bank Mega, Tbk. kemungkinan kerugian yang dihadapi bank dari risiko pasar tergolong rendah selama periode waktu tertentu di masa datang.

Good Corporate Governance (GCG)

Tabel 4

Nilai Peringkat GCG PT. Bank Mega, Tbk.

\begin{tabular}{|c|c|}
\hline Tahun & Peringkat \\
\hline 2015 & 2 \\
\hline 2016 & 2 \\
\hline 2017 & 2 \\
\hline 2018 & 2 \\
\hline
\end{tabular}

Sumber: Hasil Olahan, 2019.

Berdasarkan tabel 4, penilaian Good Corporate Governance pada PT. Bank Mega, Tbk. dari tahun 2015 hingga tahun 2018 memiliki peringkat komposit yang sama secara berturut-turut yaitu peringkat 2 dengan kategori yang diperoleh yaitu Sehat. Hal ini menunjukan bahwa PT. Bank Mega, Tbk. telah melakukan penerapan GCG yang secara umum baik. Hal ini tercermin dari pemenuhan yang memadai atas prinsipprinsip GCG. Apabila terdapat kelemahan dalam penerapan prinsip-prinsip GCG, maka secara umum kelemahan tersebut kurang signifikan dan dapat diselesaikan dengan tindakan normal oleh manajemen bank tersebut.

\section{Rentabilitas (Earnings)}

Return On Assets (ROA)

Tabel 5

Nilai ROA PT. Bank Mega, Tbk.

\begin{tabular}{|c|c|}
\hline Tahun & ROA (\%) \\
\hline 2015 & 1,97 \\
\hline 2016 & 2,36 \\
\hline 2017 & 2,24 \\
\hline 2018 & 2,47 \\
\hline
\end{tabular}

Sumber: Hasil Olahan, 2019

Berdasarkan tabel 5, dapat diketahui nilai rasio ROA yang diperoleh PT. Bank Mega, 
Tbk. ditahun 2015 yaitu sebesar 1,97\%. Pada tahun 2016 PT. Bank Mega, Tbk. mengalami peningkatan nilai rasio ROA dengan memperoleh sebesar 2,36\%. Pada tahun 2017 nilai rasio ROA yang diperoleh PT. Bank Mega, Tbk. mengalami penurunan, yaitu dengan memperoleh nilai rasio ROA sebesar 2,24\%. Kemudian ditahun 2018 mengalami kenaikan nilai rasio ROA kembali, yaitu dengan memperoleh sebesar 2,47\% ditahun 2018 dan 2,90\% ditahun 2019.

Terlihat dari tahun 2015-2018, perolehan nilai rasio ROA PT. Bank Mega, Tbk. memiliki kecenderungan semakin meningkat. Hal ini menunjukan bahwa PT. Bank Mega, Tbk. sudah semakin baik dalam memperoleh keuntungan. Hal ini disebabkan karena semakin meningkatnya nilai rasio ROA yang diperoleh maka akan semakin baik kemampuan bank tersebut dalam memperoleh keuntungan. Jika semakin menurun tingkat nilai rasio ROA yang diperoleh suatu bank maka akan semakin menurun pula kemampuan bank dalam memperoleh keuntungan, hal ini dapat terjadi dikarenakan akibat dari meningkatnya penggunaan aset oleh bank, maka akan semakin rendah pula laba yang diperoleh.

\section{Net Interest Margin (NIM)}

Tabel 6 Nilai NIM PT. Bank Mega, Tbk.

\begin{tabular}{|c|c|}
\hline Tahun & NIM (\%) \\
\hline 2015 & 6,04 \\
\hline 2016 & 7,01 \\
\hline 2017 & 5,80 \\
\hline 2018 & 5,19 \\
\hline
\end{tabular}

Sumber: Hasil Olahan, 2019.

Berdasarkan tabel 6, dapat diketahui nilai rasio NIM pada PT. Bank Mega, Tbk. dari tahun 2015 - 2018 terjadi kenaikan maupun penurunan. Ditahun 2015 diperoleh nilai rasio NIM sebesar 6,04\% yang kemudian mengalami peningkatan ditahun 2016, menjadi sebesar $7,01 \%$. Kemudian dari tahun 2017 - 2018 nilai rasio NIM yang diperoleh PT. Bank Mega, Tbk mengalami penurunan kembali menjadi sebesar 5,80\% ditahun 2017; 5,19\% ditahun 2018. Terlihat jelas nilai rasio NIM yang diperoleh PT. Bank Mega, Tbk. dari tahun 2015 - 2019 memiliki kecenderungan menurun drastis. Hal ini menunjukan bahwa dengan menurunnya nilai rasio NIM yang diperoleh suatu bank maka kemampuan suatu bank tersebut dalam menghasilkan pendapatan bunga belum baik.

Hal ini dikarenakan semakin meningkat perolehan nilai rasio NIM pada suatu bank maka akan semakin meningkat kemampuan bank tersebut dalam menghasilkan pendapatan bunga dan sebaliknya, jika semakin menurun nilai rasio NIM yang diperoleh suatu bank, maka akan semakin menurun pula kemampuan bank dalam menghasilkan pendapatan bunga.

\section{Permodalan (Capital)}

\section{Capital Adequacy Ratio (CAR)}

Tabel 7

Nilai CAR PT. Bank Mega, Tbk

\begin{tabular}{|c|c|}
\hline Tahun & CAR (\%) \\
\hline 2015 & 22,85 \\
\hline 2016 & 26,21 \\
\hline
\end{tabular}




\begin{tabular}{|l|l|}
\hline 2017 & 24,11 \\
\hline 2018 & 22,79 \\
\hline
\end{tabular}

Sumber: Hasil Olahan, 2019.

Berdasarkan tabel 7, dapat diketahui nilai rasio CAR pada PT. Bank Mega, Tbk. dari tahun 2015 - 2018 mengalami kenaikan maupun penurunan. Dapat dilihat ditahun 2015 PT. Bank Mega, Tbk. memperoleh nilai rasio CAR sebesar 22,85\%. Ditahun 2016 nilai rasio CAR yang diperoleh PT. Bank Mega, Tbk. mengalami kenaikan menjadi sebesar 26,21\%. Kemudian dari tahun 2017 - 2019 perolehan nilai rasio CAR PT. Bank Mega, Tbk. mengalami penurunan secara berturut-turut yaitu sebesar $24,11 \%$ ditahun 2017 dan 22,79\% ditahun 2018.

Terlihat nilai rasio CAR yang diperoleh PT. Bank Mega, Tbk. dari tahun 2015 - 2018 memiliki kecenderungan mengalami penurunan. Hal ini menunjukan bahwa semakin menurun nilai rasio CAR yang diperoleh suatu bank maka akan semakin menurun pula kemampuan bank dalam sistem permodalannya untuk membiayai berbagai kebutuhan operasional, perluasan cakupan usaha, maupun menangani berbagai resiko yang akan datang.Profil Risiko (Risk Profile).

\section{Non Performing Loan (NPL)}

Tabel 8 Nilai NPL PT. Bank Mega, Tbk.

\begin{tabular}{|c|c|}
\hline Tahun & NPL (\%) \\
\hline 2015 & 2,81 \\
\hline 2016 & 3,44 \\
\hline 2017 & 2,01 \\
\hline 2018 & 1,60 \\
\hline
\end{tabular}

Sumber: Hasil Olahan, 2019
Berdasarkan tabel 8 diatas, dapat diketahui perolehan nilai rasio NPL pada PT. Bank Mega, Tbk. dari tahun 2015 - 2018 terjadi fluktuasi. Dapat dilihat ditahun 2016 mengalami kenaikan nilai rasio NPL, dari yang sebelumnya memperoleh sebesar 2,81\% ditahun 2015 menjadi 3,44\% ditahun 2016. Ditahun 2017 - 2018 nilai rasio NPL mengalami penurunan, PT. Bank Mega, Tbk. memperoleh nilai rasio NPL yaitu sebesar 2,01\% ditahun 2017 dan mengalami penurunan lagi ditahun 2018, dengan nilai rasio NPL yang diperoleh yaitu sebesar $1,60 \%$. Hal ini menunjukan bahwa nilai rasio NPL PT. Bank Mega dari tahun 2015 - 2018 cenderung menurun, walaupun sempat terjadi peningkatan di tahun 2016.

Dengan nilai rasio yang semakin menurun maka kinerja pada suatu bank akan semakin baik, berlaku sebaliknya jika semakin besar nilai rasio NPL yang diperoleh maka akan semakin menurun kinerja pada suatu bank. Jika suatu bank memiliki kecenderungan menurun pada nilai rasio NPL menandakan bahwa bank tersebut sudah mampu mengatasi permasalahan kredit yang terjadi. Jika bank sudah mampu mengatasi kredit bermasalah dengan baik walaupun terjadi kredit yang dikategorikan tidak lancar, kredit yang diberikan akan tetap meningkat, sehingga bank tersebut akan tetap stabil. 


\section{Loan to Deposit Ratio (LDR)}

Tabel 9

Nilai LDR PT. Bank Mega, Tbk.

\begin{tabular}{|c|c|}
\hline Tahun & LDR (\%) \\
\hline 2015 & 65,05 \\
\hline 2016 & 55,35 \\
\hline 2017 & 56,47 \\
\hline 2018 & 67,23 \\
\hline
\end{tabular}

Sumber: Hasil Olahan, 2019

Berdasarkan tabel 9 diatas, dapat diketahui nilai rasio LDR yang diperoleh oleh PT. Bank Mega, Tbk. dari tahun 20152018 terjadi kenaikan maupun penurunan. Ditahun 2015 diperoleh nilai rasio LDR sebesar $65,05 \%$ dan mengalami penurunan ditahun 2016 menjadi 55,35\%. Kemudian ditahun 2017-2019 mengalami kenaikan nilai rasio LDR secara berturut-turut yaitu sebesar 56,47\% ditahun 2017; 67,23\% ditahun 2018.

Terlihat dari tahun 2016 - 2018, nilai rasio LDR yang diperoleh PT. Bank Mega, Tbk. memiliki kecenderungan semakin meningkat. Hal ini menunjukan bahwa semakin meningkatnya nilai rasio LDR yang diperoleh maka akan semakin menurun kinerja pada bank tersebut dalam mengelola perkreditan, karena jumlah dana yang dikeluarkan untuk keperluan kredit terlalu besar sehingga menyebabkan likuiditas semakin menurun.

\section{Risiko Pasar}

Tabel 10

Nilai Peringkat Risiko Pasar PT. Bank

\begin{tabular}{|c|c|}
\multicolumn{1}{c|}{ Mahun } & Peringkat \\
\hline 2015 & 2 \\
\hline 2016 & 2 \\
\hline 2017 & 2 \\
\hline
\end{tabular}

\section{8}

2

Sumber: Hasil Olahan, 2019

Berdasarkan tabel 10, dapat dilihat bahwa peringkat risiko pasar yang diperoleh pada PT. Bank Mega, Tbk. dari tahun 2015 - 2018 sangat stabil karena secara berturut-turut memperoleh peringkat 2. Hal ini menunjukan bahwa dengan mempertimbangkan aktivitas bisnis yang dilakukan PT. Bank Mega, Tbk. kemungkinan kerugian yang dihadapi bank dari risiko pasar tergolong rendah selama periode masa mendatang.

\section{PENUTUP}

\section{Kesimpulan}

Berdasarkan rumusan masalah, hasil penelitian, dan pembahasan yang telah dilakukan, dapat disimpulkan bahwa analisis perbandingan tingkat kesehatan bank umum pada PT. Bank Mega, Tbk. dengan menggunakan metode RGEC pada tahun 2015-2018 adalah sebagai berikut :

1. Hasil penilaian Profil Risiko (Risk Profile) PT. Bank Mega, Tbk. memperoleh Peringkat 2 dengan predikat Sehat.

2. Hasil penilaian Good Corporate Governance (GCG) PT. Bank Mega, Tbk. memperoleh Peringkat 2 dengan predikat Sehat.

3. Hasil penilaian Rentabilitas (Earnings) bank umum dengan menggunakan dua indikator yaitu dengan rasio ROA dan rasio NIM : 
a. Return On Assets (ROA)

Hasil penilaian menggunakan rasio ROA PT. Bank Mega, Tbk dari memperoleh Peringkat 1 dengan predikat Sangat Sehat.

b. Net Interest Margin (NIM)

Hasil penilaian menggunakan rasio NIM PT. Bank Mega, Tbk. memperoleh Peringkat 1 dengan predikat Sangat Sehat.

4. Hasil penilaian Permodalan (Capital) dengan menggunakan rasio Capital Assets Ratio (CAR) PT. Bank Mega, Tbk. memperoleh Peringkat 1 dengan predikat Sangat Sehat.

5. Hasil penilaian dari Aspek RGEC PT. Bank Mega, Tbk. memperoleh Peringkat 1 dengan predikat Sangat Sehat.

\section{Saran}

Dari hasil kesimpulan dalam penelitian ini, penulis memberikan saran sebagai berikut:

1. Bagi Pihak Bank

a. Sebaiknya untuk PT. Bank Mega, Tbk. harus mampu mempertahan-kan dan meningkatkan kesehatan bank dengan cara meningkatkan kinerja manajemen bank pada tahun-tahun selanjutnya. Karena semakin meningkat tingkat kesehatan bank maka akan semakin meningkat pula tingkat kepercayaan masyarakat, nasabah, pemegang saham, dan juga pihak lainnya untuk menyalurkan dananya kepada bank.

b. Pada indikator-indikator yang mengalami penurunan diharapkan untuk ditingkatkan kembali karena dapat berakibat buruk bagi perusahaan. Dan untuk meminimalisir terjadinya risiko kredit diharuskan ada pengawasan lebih dalam memberikan kredit yang diberikan.

2. Bagi Peneliti Selanjutnya

Bagi penelitian selanjutnya, diharapkan agar peneliti memperluas cakupan penelitian tentang analisis perbandingan tingkat kesehatan bank dengan menggunakan indikator rasio keuangan yang lainnya pada pengukuran tingkat kesehatan bank dan juga menambah kurun waktu yang lebih panjang agar diperoleh perhitungan, analisis yang lebih menyeluruh, dan akurat dalam perhitungan kinerja bank dengan menggunakan metode RGEC.

\section{DAFTAR PUSTAKA}

Bank Indonesia, Lampiran Surat Edaran Bank Indonesia No.13/24/DPNP Perihal Penilaian Tingkat Kesehatan Bank Umum, Bank Indonesia, Jakarta, 2011.

Bank Indonesia, Peraturan Bank Indonesia Nomor: 13/1/PBI/2011 Perihal Penilaian Tingkat Kesehatan Bank Umum, Bank Indonesia, Jakarta, 2011.

Bank Indonesia, Surat Keputusan Direksi Bank Indonesia No. 30/267/KEP/DIR Perihal Kualitas Aktiva Produktif, Bank Indonesia, Jakarta, 1998. 
Bank Mega, Laporan Keuangan Bank Mega, Bank Mega, Jakarta, 2015, 2016, 2017, 2018, 2019.

Emilia, E., 2017. Analisis Tingkat Kesehatan Bank dengan Metode Rgec (Risk Profile, Good Corporate Governance, Earnings, and Capital) pada PT. BNI Syariah.[SKRIPSI] (Doctoral dissertation, UIN RADEN FATAH PALEMBANG).

https://www.bankmega.com [27 Maret 2021] https://www.idx.com [27 Maret 2021]

Ikatan Akuntan Indonesia, Standar Akuntansi Keuangan per 1 September 2007, Salemba Empat, Jakarta, 2007.

Ikatan Bankir Indonesia, Memahami Bisnis Bank, Edisi 1, PT. Gramedia Pustaka Utama, Jakarta, 2013.

Kasmir, D., 2011. Analisis Laporan Keuangan, Raja Grafindo Persada, Jakarta.

Kasmir, D., 2012. Manajemen Perbankan edisi revisi. Jakarta: Penerbit PT Raja Grafindo Persada.

KHUDORI, A., 2018. Analisis Penilaian Tingkat Kesehatan Bank Syariah Berdasarkan Metode RGEC Tahun 2012-2016. JAE (Jurnal Akuntansi Dan Ekonomi), 3(1), pp.12-34.

Munawir, S., 2004. Analisa Laporan Keuangan, Edisi keempat Yogyakarta:
Liberty Purwaningsih, Anna. 2008. Pemilihan Rasio Keuangan Terbaik untuk Memprediksi Peringkat Obligasi: Studi pada Perusahaan Manufaktur yang Terdaftar di BEJ.

Raharjo, A.W., 2020. Bank dan lembaga keuangan non bank di Indonesia.

Rahayu, D. and Suhendro, S., 2016. Health Analysis of Bank Mandiri and Bank BCA with RGEC Method 20102014. Jurnal Ilmiah Wahana Akuntansi, 11(1), pp.1-14.

Sawir, A., 2005. Analisis kinerja keuangan dan perencanaan keuangan perusahaan.

Sulhan, M. and Siswanto, S., 2008. Manajemen Bank: Konvensional dan Syariah. UIN-Maliki Press.

Sutrisno, H., 2009. Manajemen keuangan teori, konsep dan aplikasi. Yogyakarta: Ekonosia.

Taswan., 2012. Akuntansi Perbankan Transaksi Dalam Valuta Rupiah.

Triandaru, S. and Budisantoso, T., 2006. Bank dan Lembaga Keuangan Lain. Jakarta: Salemba Empat.

Triandaru, S. and Budisantoso, T., 2006. Bank dan Lembaga Keuangan Lain. Jakarta: Salemba Empat. 